\title{
Late Holocene plant and climate evolution at Lake Yoa, northern Chad: pollen data and climate simulations
}

\author{
A.-M. Lézine ${ }^{1}$, W. Zheng ${ }^{2}$, P. Braconnot ${ }^{1}$, and G. Krinner ${ }^{3}$ \\ ${ }^{1}$ Laboratoire des Sciences du Climat et de l'Environnement, UMR8212, CNRS-CEA-UVSQ, Orme des Merisiers, \\ Bâtiment 701, 91191 Gif-sur-Yvette cedex, France \\ ${ }^{2}$ LASG, Institute of Atmospheric Physics, Chinese Academy of Sciences, P.O. Box 9804, 100029 Beijing, China \\ ${ }^{3}$ Laboratoire de Glaciologie et Géophysique de l'Environnement, UMR5183, CNRS-UJF Grenoble, Domaine Universitaire, \\ 54 Rue Molière, BP 96, 38402 St Martin d'Hères cedex, France
}

Received: 27 June 2011 - Published in Clim. Past Discuss.: 19 July 2011

Revised: 11 October 2011 - Accepted: 9 November 2011 - Published: 9 December 2011

\begin{abstract}
The discovery of groundwater-fed Lake Yoa $\left(19.03^{\circ} \mathrm{N}, 20.31^{\circ} \mathrm{E}\right)$ in the hyperarid desert of northern Chad by the German research team ACACIA headed by S. Kröpelin provides a unique, continuous sedimentary sequence of late Holocene age available in the entire Saharan desert. Here we present pollen data and climate simulations using the LMDZ atmospheric model with a module representing the climatologically-relevant thermal and hydrological processes occurring above and beneath inland water surfaces to document past environmental and climate changes during the last $6000 \mathrm{cal}$ yr BP. Special attention is paid to wind strength and direction, length and amplitude of the rainy season, and dry spell occurrence, all of which are of primary importance for plant distribution and pollen transport. In addition to climate changes and their impact on the natural environment, anthropogenic changes are also discussed. Two main features can be highlighted: (1) the shift from an earlier predominantly monsoonal climate regime to one dominated by northern Mediterranean fluxes that occurred after 4000 cal yr BP. The direct consequence of this was the establishment of the modern desert environment at Yoa at 2700 cal yr BP. (2) Changes in climate parameters (simulated rainfall amount and dry spell length) between 6 and 4000 cal yr BP were comparatively minor. However, changes in the seasonal distribution of precipitation during this time interval dramatically affected the vegetation composition and were at the origin of the retreat of tropical plant communities from Lake Yoa.
\end{abstract}

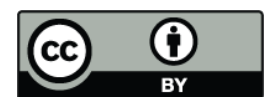

Correspondence to: A.-M. Lézine (anne-marie.lezine@lsce.ipsl.fr)

\section{Introduction}

The timing and amplitude of the transition between the "green Sahara" and the present-day hyperarid desert at the end of the African Humid Period (AHP) is still a matter of debate. Several authors have discussed the role of the vegetation feedback in triggering the long-term southward shift of the boreal summer limit of monsoon flow. It is widely admitted, following Charney et al. (1975), that changes in plant cover and related land-surface albedo have had considerable effects on monsoon fluctuations in the past and that a positive feedback between climate and vegetation has lead to amplification of orbital forcing. This has been intensely investigated with transient simulations around the AHP using intermediate complexity models (e.g. Claussen et al., 1999; Renssen et al., 2006; Liu et al., 2007). Liu et al. (2007), however, questioned the role of such a vegetation feedback and suggested that the drying out of the Sahara was linked to increased variability involving changes in soil moisture and the response of the vegetation to a stochastic force.

De Menocal et al. (2000) suggested that this transition occurred abruptly, as recorded by the dramatic increase in terrigenous (eolian) sediment deposition in ODP core 658 at $5.5 \mathrm{kaBP}$. This was interpreted as reflecting the decrease in grass cover on the nearby continent and the drying out of the Saharan desert. However, analyses of past indicators, such as archaeological records (Kuper and Kröpelin, 2006) and water bodies (Gasse, 2000; Lézine et al., 2011), suggest that the transition occurred gradually at the sub-continental scale. Local records of abrupt environmental changes, as observed in the western Sahel (Lézine, 1988), probably accounted for specific environmental (hydro-geological) settings, as

Published by Copernicus Publications on behalf of the European Geosciences Union. 


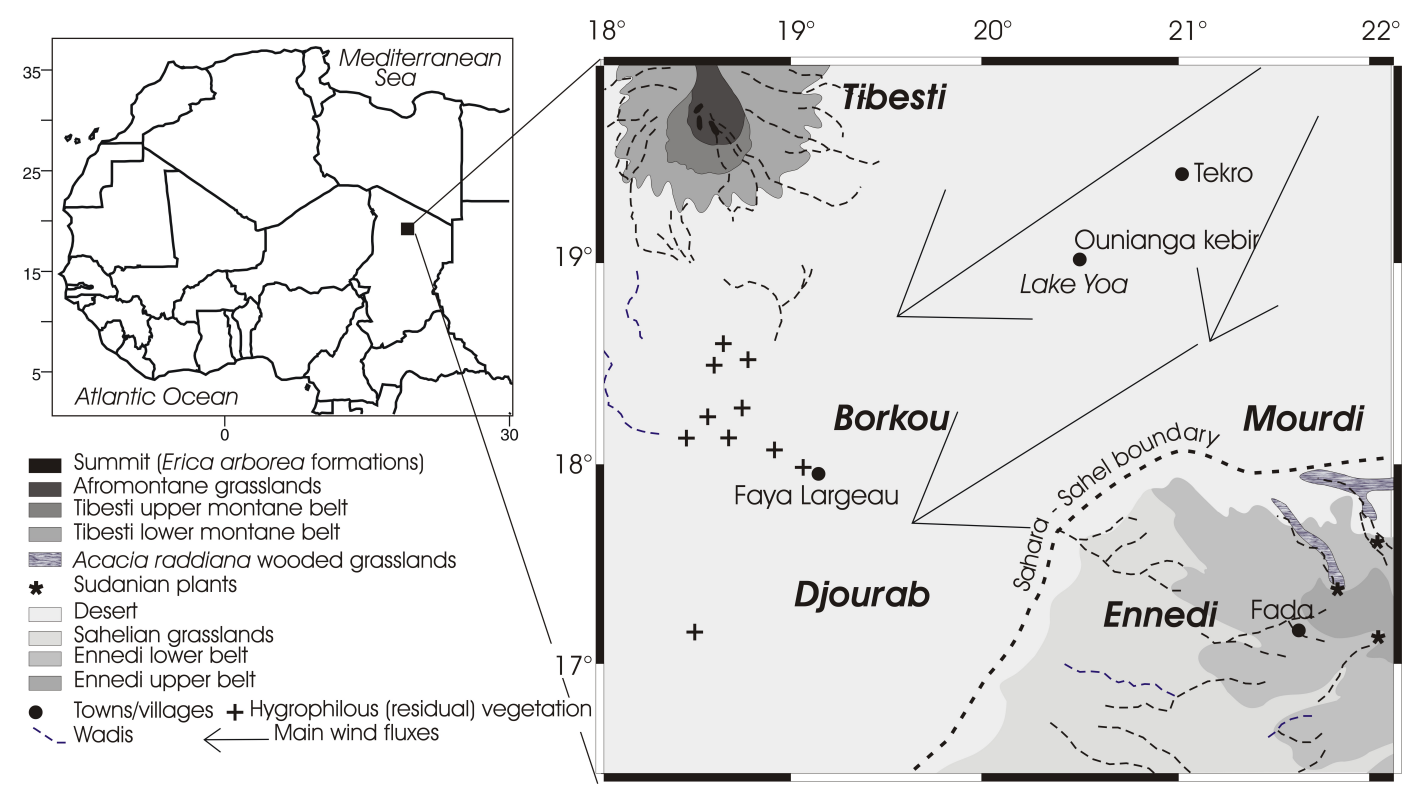

Fig. 1. Synthetic vegetation map of Faya Largeau (redrawn from Quézel, 1964 and Capot-Rey, 1961).

observed elsewhere in the tropics (Vincens et al., 1999; Lézine, 2009). Thus, there is a need to refine the interpretation of proxy records in the Sahel-Sahara region. Unfortunately, late Holocene pollen data in this region are extremely rare on land, owing to the discontinuity of most sedimentary archives under predominantly arid climate conditions. Furthermore, none of the pollen sites from Northern Africa located between 18 and $25^{\circ} \mathrm{N}$ provide a continuous record of the last few thousand years, i.e. from the end of the AHP to the present day (Watrin et al., 2009), preventing any discussion on the timing and amplitude of the paleoenvironmental change at that time.

The discovery (Kröpelin et al., 2008) of a groundwater-fed lake in the hyperarid desert of northern Chad yields a unique, continuous sedimentary sequence of late Holocene age available in the entire Saharan desert. Lake Yoa $\left(19.03^{\circ} \mathrm{N}\right.$, $20.31^{\circ} \mathrm{E}, 380 \mathrm{~m}$ a.s.l. - above sea level, $24.3 \mathrm{~m}$ water depth) lies roughly on the $28^{\circ} \mathrm{C}$ isotherm in the hyperarid sector of northern Chad, located between the Tibesti and the Ennedi massifs. Meterological data for this site derived from the nearby station of Faya Largeau (World Climate Database, 2007) and ancient observations reported in Capot-Rey (1961) and Quézel (1964) indicate that temperatures record high diurnal amplitude, from a maximum of $49^{\circ} \mathrm{C}$ in April-May to a minimum of $13{ }^{\circ} \mathrm{C}$ in December-February. Precipitation is very low, occurring between April and October with a maximum in August $(7 \mathrm{~mm})$. Strong $\mathrm{N}$ and $\mathrm{NE}$ winds, blowing from October to April, are responsible for intense sand transport and sand spit formation across Lake Yoa and all the other Ounianga lakes (Arkell, 1964). Infrequent, gentle winds in the opposite direction blow during summer. The estimated annual mean value of evaporation is $6100 \mathrm{~mm}$ (Kröpelin et al., 2008). As a result of these hyperarid environmental conditions, plant communities are rare throughout vast tracts of plantless ergs, hammadas and regs, and their occurrence appears to depend directly on water availability from the water table or surficial runoff (Capot-Rey, 1961; Quézel, 1965; Gillet, 1968) (Fig. 1).

The objective of this study is twofold. First, we provide an analysis of pollen data from Core OUNIK03/04 located in the northeastern sector of Lake Yoa in order to describe the evolution of the major ecosystems and discuss adaptation of plants to the shift from moist to arid conditions during the last 6000 years and the establishment of the modern Saharan desert. Then using the results of climate simulations combining a global climate model and regional simulations with a zoomed atmospheric model, we discuss the possible link between the evaluation of the vegetation recorded at Yoa and climate characteristics. A particular focus is put on wind regimes and dry spells that are the two climate variables that best reflect the changes related to long term reduction of boreal summer monsoon activity in West Africa. Even though we cannot discuss the role of the vegetation changes on the climate, a consistent picture emerges from the comparison of the simulated climate and the climate hypothesis raised from our data.

The paper is organized as follows. After a presentation of the modern distribution of plants in the Lake Yoa area, Sect. 2 presents the pollen analyses and isolates the different key periods in the last 6000 years from the data. Section 3 presents the results of model output. Discussion and concluding remarks are provided in Sects. 4 and 5, respectively. 


\section{Modern and past vegetation around Lake Yoa}

\subsection{Modern plant distribution}

The Lake Yoa regional environment is dominated by steppic plant communities with scattered herbs (Aristida, Indigofera, Cornulaca, Aerva, Fagonia, Neurada) in associations with rare trees (Capparis decidua, Acacia raddiana, A. seyal and Maerua crassifolia) (Fig. 1). When the water table reaches the surface, trees become more abundant (Acacia raddiana, A. seyal, A. adstringens, Faidherbia albida, Hyphaene thebaica, Tamarix brachystilis and T. articulata) and Eragostis, Imperata and Typha occur.

A steep gradient of increasing plant occurrence and diversity occurs to the south-east (the Ennedi plateau) and to the west (the Tibesti massif) along a rainfall gradient from approximately $10 \mathrm{~mm}$ to $200 \mathrm{~mm}$ (Maire and Monod, 1950; Quézel, 1965; Gillet, 1968). Sahelian grasslands and wooded grasslands with Acacia raddiana, Cenchrus biflorus, Aristida funiculata and Panicum turgidum expand along the western flank of the Ennedi. A "lower vegetation belt" has been identified in this massif, with Acacia mellifera and Indigofera suaveolens on rocky places, while an upper belt is characterized by Achyroclime luzuloides, Vernonia aschersonii with Albizzia sercocephala in wadis, and Acacia stenocarpa and $A$. scorpioides on temporarily inundated places. Relict species of Sudanian and Sudano-Guinean phytogeographical affinity sporadically grow in restricted areas along wadis and temporary ponds, confirming the former extent of tropical humid environmental conditions with, among others, Parkia biglobosa, Isoberlinia doka, Anogeissus leiocarpus, Stereospermum kunsthianum, Rauvolfia cafra, Ficus populifolia, Syzygium guineense, Vitex doniana, Piliostigma reticulatum, and Diospyros mespiliformis.

On the Tibesti massif, which reaches up to $3415 \mathrm{~m}$ alt. at the Emi Koussi summit, five specific vegetation associations have been distinguished: the lower montane belt is characterized by Acacia flava, Ziziphus mauritania, Capparis decidua and Ruellia patula. Then, between roughly 1800 and $2500 \mathrm{~m}$ alt, the montane belt is highly diverse with numerous plants of southern Sahelian origin. Here, annual rainfall averages $150 \mathrm{~mm}$, allowing Acacia stenocarpa, A. laeta, Erhetia obtusifolia, Rhus incanum, and Ficus spp. to grow. Upward, trees mostly disappear and the upper limit of the tree line (between 2500 and $3000 \mathrm{~m}$ ) is marked by the presence of $E r$ ica arborea (Bruneau de Miré and Quézel, 1959). Above, the summit is characterized by grasslands of Mediterranean affinity with, e.g. Helianthemum sp., Aristida coerelescens and A. obtus.

\subsection{Core OUNIK03/04 pollen data}

Core OUNIK03/04 is composed of two overlapping sections recovered from the northeastern sector of Lake Yoa $\left(19.03^{\circ} \mathrm{N}, 20.31^{\circ} \mathrm{E}, 380 \mathrm{~m}\right.$ a.s.l., $24.3 \mathrm{~m}$ water depth). Field

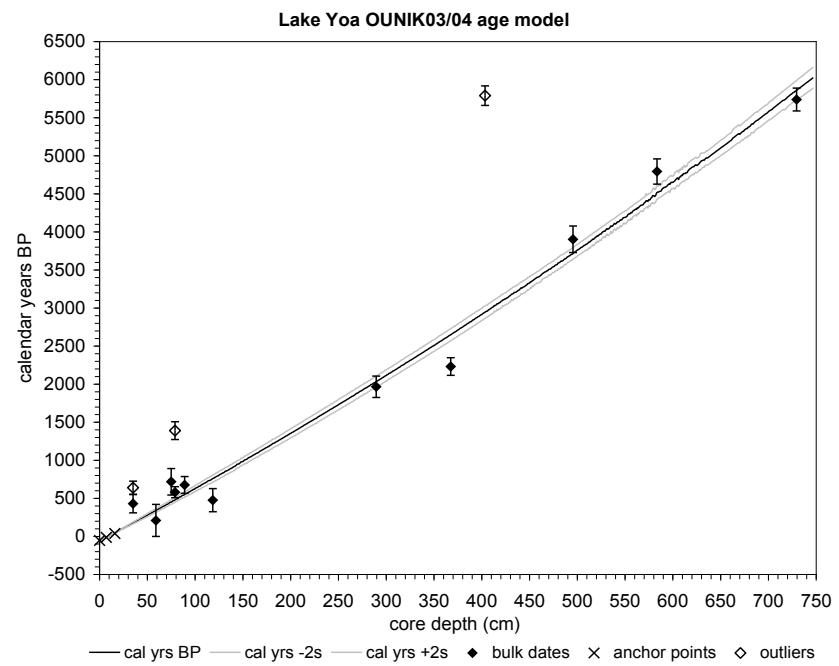

Fig. 2. Calendar age-depth model for the composite OUNIK03/04 core from Lake Yoa (from Kröpelin et al., 2008).

methods, sediment composition, and chronology have been detailed elsewhere (Eggermont et al., 2008; Kröpelin et al., 2008) (Fig. 2). The $7.49 \mathrm{~m}$ long sediment core is composed of finely laminated clayey and sandy muds deposited from $6000 \mathrm{BP}$ to the present with a sediment rate averaging $0.10-0.15 \mathrm{~cm}$ per year. The sediment core has been sampled at $8 \mathrm{~cm}$ interval for pollen studies. Ninety-one samples (each $1 \mathrm{~cm}^{3}$ ) were processed according to standard procedures (chemical treatment with HCL and HF; sieving at $5 \mu \mathrm{m}$ ) and analyzed. They yielded an abundant microflora of 167 pollen and spore taxa for pollen counts ranging between 88 and 848 according to the samples. Pollen identification was performed using the extensive reference material of the Museum National d'Histoire Naturelle (Paris), electronic photographs from the African Pollen Database (http://www://medias.obs-mip.fr/apd) and published pollen atlases (Maley, 1970; Bonnefille and Riollet, 1980). Nomenclature follows Lebrun and Stork (1991-1997) and Vincens et al. (2007). Percentages were calculated against a sum including all the determinable pollen grains and fern spores (Figs. 3 and 8). The addition of a known concentration of an exotic pollen taxon (Alnus) prior to processing made possible estimates of pollen and spore fluxes (number of grains per $\mathrm{cm}^{2}$ per year) (Fig. 8).

Pollen taxa have been assigned to several ecological and phytogeographical groups according to Maire and Monod (1950), Hutchinson and Dalziel (1954-1972), Bruno de Miré and Gillet (1956), Quézel (1965), Gillet (1968), Wickens (1976), White (1986), Ozenda (2004) and the on line African Plant database (2009) developed by the Conservatoire et Jardin botaniques de Genève and the South African National Biodiversity Institute (S Table in Supplement): 


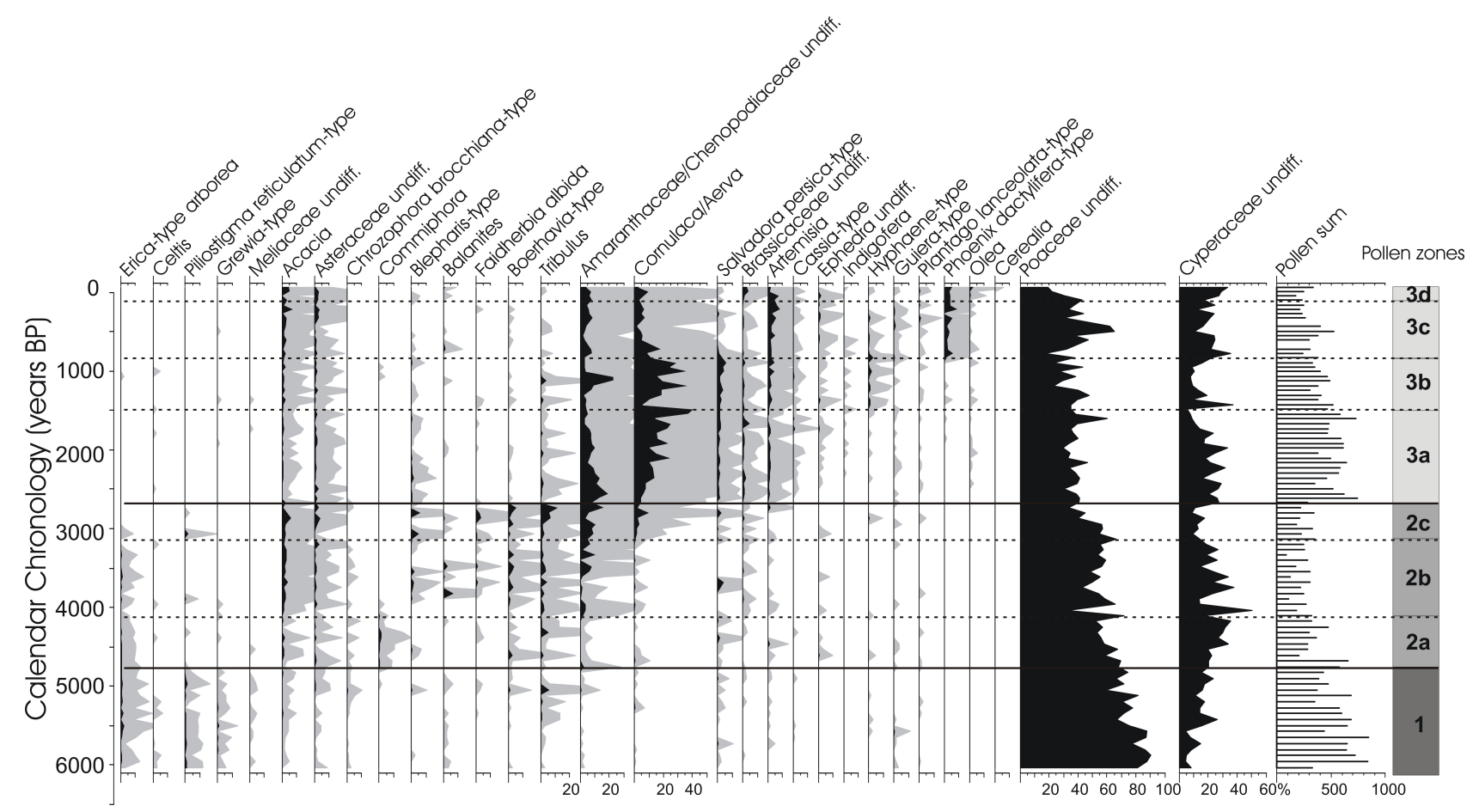

Fig. 3. Lake Yoa synthetic pollen diagram of percentages versus time. Only the major pollen types are presented.

- Taxa from local lake-shore and river bank communities: reed-swamp populations ( 6 taxa) and ferns ( 6 taxa). Grasses and sedges were considered separately because of their wider ecological range including drier areas.

- Taxa of tropical affinity that can be subdivided into five groups: tropical undifferentiated with a broad modern phytogeographical range (20 taxa), Sudanian (including "tropical humid" plant types (19 taxa)), Sahelian s.l. (including Sahelian (9 taxa), Saharo-Sahelian (39 taxa) and Sudano-Sahelian plant types (23 taxa)), Saharan (including Saharo-Mediterranean plant types) (28 taxa), and Tropical Mountains (4 taxa).

- Taxa of northern origin: Mediterranean (6 taxa) and European-Temperate (5 taxa).

Some pollen taxa may have several possible origins:

- Olea is not reported in the Tibesti massif (Quézel, 1965). However, an olive tree species, Olea laperrini, endemic to the Ahaggar (Quézel, 1954), dominated mid-Holocene vegetation at roughly $2000 \mathrm{~m}$ alt (Thinon et al., 1996). Given its complete absence in the contemporaneous core interval at Lake Yoa, this species is unlikely to be the source of Olea pollen deposited after 2500 cal yr BP (Kröpelin et al., 2008). It is much more probable that Olea pollen from Lake Yoa sediments originates from the Mediterranean region where it is currently widely cultivated.
- Artemisia and Ephedra plant species are present in the upper belts of the Tibesti massif. They also widely spread at the Saharan-Mediterranean transition. Modern soil samples and aerosols studies from Northern Africa (Van Campo, 1975; Schulz, 1980) show that the corresponding pollen grains rapidly decrease with the distance from values higher than 45 and $20 \%$, respectively, to the north, near the Mediterranean sea, to less than $1 \%$ south of $20^{\circ} \mathrm{N}$. Artemisia and Ephedra pollen are only sporadically found southwards in modern samples from the Sahel (Caratini et al., 1988; Lézine and Hooghiesmtra, 1990 ; Schulz and Leke, 2009), testifying for long distance pollen transport by continental trade wind fluxes. Artemisia and Ephedra dominate the upper levels of the Lake Yoa pollen diagram, in association with other Mediterranean pollen types (Olea, $\mathrm{Pi}$ nus, Asteraceae, Plantago). Their source is most probably located in the Mediterranean region.

- The nearest populations of Erica arborea are found today in the Emi Koussi crater where they are considered a relict of former wider populations (Bruneau de Miré and Quézel, 1959). This agrees with earlier studies carried out in the Ahaggar at $2000 \mathrm{~m}$ alt (Pons and Quézel, 1958) which record abundant pollen grains of Erica arborea between 5330 and 5660 cal yr BP. Scattered Erica pollen have also been found in lowland Holocene sites from Borkou (Quézel and Martinez, 1958) and Sudan (Ritchie et al., 1985; Ritchie and Haynes, 1987) 
between 8100 and 5330 cal yr BP, confirming that this species expanded in all the Saharan massifs during the Holocene. Erica arborea also grows in the Mediterranean region today within Quercus suber forests. Its pollen is however badly dispersed and never exceeds more than few grains even when near the source area. It is not found in modern surface samples south of $22^{\circ} \mathrm{N}$ (Van Campo, 1975; Schulz, 1980). The source area of Erica arborea recovered from Yoa is most likely the Tibesti massif.

The physiognomy of the source plants has been determined, and two categories have been distinguished: the arboreal pollen group including trees, palms, epiphytes, lianas and shrubs; and the non-arboreal group including herbs. Undifferentiated pollen types are taxa with low taxonomical range corresponding to trees, shrubs, herbs or lianas. As is common in arid palynology (e.g. Ritchie et al., 1985; Ritchie and Haynes, 1987; Lézine et al., 1990; Vincens, 1982), pollen grains of local herbaceous plant communities (Poaceae, Cyperaceae, Amaranthaceae-Chenopodiaceae) are several orders of magnitude more numerous than those of tropical trees, because the later are primarily zoophilous taxa with low pollen production and dispersal. However, Watrin et al. $(2007,2009)$ demonstrated that even when found in low percentages, the arboreal taxa can be considered with confidence as indicators of the local presence of the corresponding plants. In consequence, the pollen zones described below are not only based on the fluctuations of the major pollen types but also on the appearance/disappearance of the most characteristic taxa. Three main zones can be distinguished.

\subsubsection{Pollen zone $1(6000-4750$ cal BP $)$}

This zone exhibits the predominance among the regional arboreal taxa of tropical humid (Sudanian) elements, of which Piliostigma reticulatum, Celtis, Meliaceae, and Grewia are noticeable. Erica arborea, from nearby montane plant communities, occurs continuously at significant values throughout this zone along with fern spores from near shore lake and river bank communities. Poaceae reaches a maximum value $(90 \%)$ at the base of this zone and then regularly decreases toward the top of the sedimentary sequence to $17 \%$ (zone 3d).

\subsubsection{Pollen zone 2 (4750-2700 cal BP)}

This transition zone records the progressive increase of dry indicators. Pollen types from northern origin, mainly Pinus, reach their maximum values $(3 \%)$. Acacia, which occurs only sporadically at low values in zone 3 , increases from the base of this zone to the top of the sedimentary sequence, averaging $2 \%$ (maximum $=8 \%$ ). Zone 2 can be further subdivided in three sub-zones:

- Sub-zone 2a (4750-4000 cal BP): all the humid indicators (Sudanian plant types and ferns) disappear in this zone, which is defined by the continuous occurrence at significant values of Commiphora, a drier, Sahelian (Sahelo-Sudanian) taxon. Erica arborea remains present in high abundance. AmaranthaceaeChenopodiaceae associated with characteristic Saharan and Sahelo-Saharan plant types (e.g. Tribulus, Boehravia and Salvadora persica) started to expand at the end of the previous zone and is continuously present.

- Sub-zone 2b (4000-3250 cal BP): Commiphora disappears and is replaced by Balanites aegyptiaca and Faidherbia albida of Sahelo-Saharan affinities. Amaranthaceae-Chenopodiaceae, Tribulus and Boehravia significantly increase.

- Sub-zone 2c (3250-2700 cal BP): this last sub-zone is defined by the disappearance of Erica arborea and the progressive increase in Saharan and SaharoMediterranean elements like Aerva/Cornulaca, Amaranthaceae-Chenopodiaceae, Brassicaceae, Asteraceae and Artemisia.

\subsubsection{Pollen zone 3 (2700 cal BP-present day)}

This zone is typified by the dominance of AmaranthaceaeChenopodiaceae and Saharo-Mediterranean elements, mainly Aerva/Cornulaca (maximum $=41 \%$ ), Artemisia, Ephedra and the appearance of Mediterranean pollen types such as Olea. Successive increase in Hyphaene and Phoenix percentages allows distinction of sub-zone $3 \mathrm{~b}$ (1500-850 cal $\mathrm{BP}$ ) and sub-zone $3 \mathrm{c}$ (850 cal BP-present day), respectively. The uppermost levels (sub-zone 3d) differ greatly from the lowest ones, exhibiting the dramatic increase in Mediterranean and temperate pollen types and the appearance of Cerealia pollen.

\section{Snapshot experiments for $6 \mathrm{ka}, 4 \mathrm{ka}$ and $0 \mathrm{k}$}

\subsection{Climate simulations}

In order to discuss links between vegetation and climate, we consider the simulations of mid-Holocene climate discussed in Krinner et al. (2011) that account for the changes in insolation forcing and feedbacks from vegetation and lakes. These simulations were run using a version of the LMDZ atmospheric model (Hourdin et al., 2006) in which a module representing the climatologically-relevant thermal and hydrological processes occurring above and beneath inland water surfaces has been included (Krinner et al., 2004). This global atmospheric model was zoomed over Africa to reach a regional resolution of 1 to $1.5^{\circ}\left(30^{\circ} \mathrm{N}\right)$. Orbital parameters were prescribed to those of $6 \mathrm{kaBP}$, and changes in vegetation were computed using an asynchronous coupling between the atmospheric model and the BIOME 4 equilibrium vegetation model (Kaplan et al., 2003). Two iterations of a 

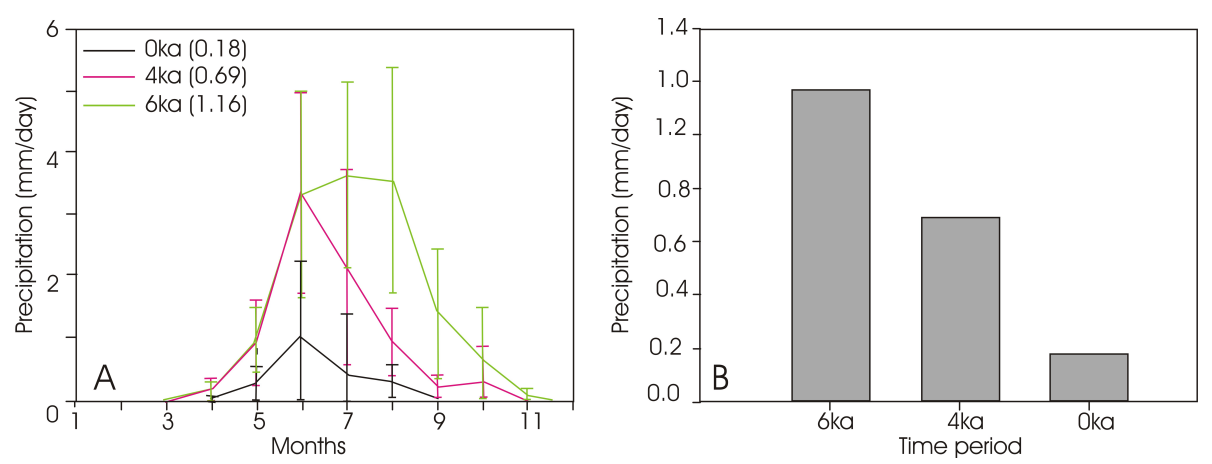

Fig. 4. Precipitation $\left(\mathrm{mm} \mathrm{day}^{-1}\right)$ over Lake Yoa region $\left(17.5-22.5^{\circ} \mathrm{E}, 17-22^{\circ} \mathrm{N}\right)$ simulated for $6 \mathrm{ka}$, $4 \mathrm{ka}$ and $0 \mathrm{ka}$. (A) Monthly mean seasonal cycle. The error bars represent the standard deviation representing interannual variability and are estimated using 41 year of simulated data. (B) Annual mean.

four-decade AGCM run, followed each time by a BIOME 4 simulation of the corresponding vegetation distribution, are carried out. A final 42-year AGCM simulation is then used for the analysis of the results presented here. The second and third AGCM iteration yield very similar precipitation rates, indicating that equilibrium of the coupled system is attained. The fraction of the land surface occupied by inland water bodies was prescribed following Hoelzmann et al. (1998). The response of the ocean to insolation forcing was considered using sea surface temperatures (SSTs) from mid-Holocene simulations of the IPSL global coupled general circulation model (Marzin and Braconnot, 2009). A SST climatology was computed from the last 200 years of the $>700$ year long simulations with the IPSL model. The differences between the SST annual mean cycle computed for $6 \mathrm{ka} \mathrm{BP}$ and pre-industrial SSTs were added to the modern SST climatology. The reference is thus a simulation of the modern climate forced by with the 1980-2000 HADISST climatology (Rayner et al., 2003). The concentrations of the principal greenhouse gases were also adjusted for each time period.

During the second half of the Holocene, the changes in incoming solar radiation at the top of the atmosphere are driven by changes in the Earth's obliquity and precession. This induced changes in latitudinal thermal gradients and seasonality that affected the characteristics of the African monsoon (Hely et al., 2009). This is why we consider a simulation of $4 \mathrm{kaBP}$ climate in addition to the $6 \mathrm{kaBP}$ simulation. The experimental protocol is the same as that used for $6 \mathrm{ka}$. Orbital parameters are prescribed following Berger (1978), and the changes in SSTs come from a simulation of the IPSL climate model (Marzin and Braconnot, 2009). Since there is no available reconstruction of inland water bodies that can be used as boundary conditions for this period, the Hoelzmann et al. (1998) reconstruction is used for $6 \mathrm{ka} \mathrm{BP}$; however, this may overestimate the effects of lakes in this simulation.

\subsection{Simulated climate characteristics}

In the following we consider the last 41 years of the final AGCM run focusing on the mean climatology and daily values for temperature, precipitation, and $10 \mathrm{~m}$ wind over a region extending from $17^{\circ} \mathrm{N}$ to $22^{\circ} \mathrm{N}$ and $17.5^{\circ} \mathrm{W}$ to $22.5^{\circ} \mathrm{E}$. The size of the box is a compromise that allows for inferring the large scale climate changes that have driven the major climate characteristics over Yoa yet remain representative of Yoa climate. We do not consider local changes in this analysis that could have affected the geographical pattern of vegetation around core OUNIK03/04.

Figures 4 and 5 show, respectively, the simulated precipitation as a function of month and the frequency and amplitude of winds during DJF and JJAS as a function of wind direction indicated by the wind compasses (wind rose). These wind compasses were computed by dividing the wind direction into 8 sectors. The average strength and angles in each of these directions is used to define the wind amplitudes and dominant direction. For present day, the simulations show that precipitation occurs from April to September with a maximum in June. The maximum occurs slightly earlier than in the observations, but the rainfall amount is quite well represented (Fig. 4). During winter (DJF, 90 days), the region is under the influence of strong (Table $1,3.3 \mathrm{~m} \mathrm{~s}^{-1}$ ) north-easterly (mainly east-north east phase) winds, indicating that Lake Yoa is mainly tied to climate in the Mediterranean region in winter (Fig. 5). During the summer (JJAS, 120 days), it is also under the influence of north-easterly winds, but most of the events come from the north-north east phase. The wind amplitude from this sector is much weaker (Table $1,1.16 \mathrm{~m} \mathrm{~s}^{-1}$ ) than in winter. As in the observations, only rare south-westerly wind events are simulated and are always of small amplitude (Fig. 5, Table 1). Only 4 events are found in the 0 ka simulation, showing a very weak monsoonal flow over this region. The region is therefore mainly located in a subsidence zone (Fig. 6) and is subject to only a small fraction of convective events. 
Table 1. Characterization of wind regimes over the Yoa region $\left(17.5-22.5^{\circ} \mathrm{E}, 17-22^{\circ} \mathrm{N}\right)$ as reconstructed from the atmospheric simulations for $0 \mathrm{ka}, 4 \mathrm{ka}$ and $6 \mathrm{ka}$ from daily values.

\begin{tabular}{|c|c|c|c|c|c|c|c|c|c|c|c|}
\hline \multicolumn{4}{|c|}{ Summer $0 \mathrm{ka}$} & \multicolumn{4}{|c|}{ Summer $4 \mathrm{ka}$} & \multicolumn{4}{|c|}{ Summer $6 \mathrm{ka}$} \\
\hline Direction & Amplitude & $\mathrm{Nb}$ & Angle & Direction & Amplitude & $\mathrm{Nb}$ & Angle & Direction & Amplitude & $\mathrm{Nb}$ & Angle \\
\hline SSW & 0.1026 & 1 & 197.88 & SSW & 0.3345 & 10 & 211.11 & SSW & 0.8976 & 9 & 223.179 \\
\hline WSW & 0.0729 & 3 & 247.93 & WSW & 0.3568 & 21 & 247.25 & WSW & 0.8287 & 84 & 238.41 \\
\hline NNW & 0.1343 & 4 & 327.56 & WNW & 0.438 & 23 & 294.7 & WNW & 0.2251 & 5 & 286.5 \\
\hline NNE & 1.1664 & 98 & 30.1 & NNW & 0.5298 & 19 & 340.28 & NNW & 0.2421 & 3 & 352.97 \\
\hline \multirow[t]{4}{*}{ ENE } & 3.1047 & 14 & 46.06 & NNE & 1.4011 & 35 & 30.12 & NNE & 0.8534 & 19 & 31.02 \\
\hline & & & & ENE & 0.1346 & 10 & 70.15 & & & & \\
\hline & & & & ESE & 0.05189 & 1 & 109.55 & & & & \\
\hline & & & & SSE & 0.0435 & 1 & 151.1 & & & & \\
\hline \multicolumn{4}{|c|}{ Winter $0 \mathrm{ka}$} & \multicolumn{4}{|c|}{ Winter $4 \mathrm{ka}$} & \multicolumn{4}{|c|}{ Winter $6 \mathrm{ka}$} \\
\hline Direction & Amplitude & $\mathrm{Nb}$ & Angle & Direction & Amplitude & $\mathrm{Nb}$ & Angle & Direction & Amplitude & $\mathrm{Nb}$ & Angle \\
\hline & & & & $\mathrm{NNE}$ & 3.0906 & 2 & 44.75 & $\mathrm{NNE}$ & 2.8904 & 2 & 44.79 \\
\hline ENE & 3.348 & 90 & 49.5 & ENE & 2.9636 & 88 & 48.44 & ENE & 2.8129 & 88 & 48.28 \\
\hline
\end{tabular}

\subsection{Simulated dry spells}

Vegetation is very sensitive to the length of the dry season as well as the persistence of dry events or dry months. This cannot be directly inferred from the convection regimes or the mean seasonal cycle of precipitation. This is why we also computed the number of dry months. For the modern climate, a dry day is defined as a day with an amount of precipitation less than a pre-defined threshold, and a dry spell is defined as extended period of dry days. This later metric is widely used as indicator of drought conditions (e.g. Benniston et al., 2007). Here we call a dry spell a dry period during which the monthly rainfall is below $1 \mathrm{~mm} \mathrm{day}^{-1}$ over a period lasting longer than 5 months. As expected from the simulated precipitation between the 3 climate periods, aridification at Yoa is associated to an increase in the length of dry spells (Fig. 7).

\section{Discussion}

\subsection{Environmental and climate changes}

The Lake Yoa pollen record shows the progressive retreat of tropical plant communities, which were widely spread throughout North Africa (Watrin et al., 2009) during the Holocene, and their replacement by herbaceous-dominated desert ecosystems (Fig. 8).

From 6000 to $4750 \mathrm{cal} \mathrm{BP}$, occurrence of a highly diverse tropical pollen flora together with ferns, the spores of which are well known to be primarily carried by rivers (Tschudy, 1969), indicates that a monsoonal climatic regime prevailed during this time. The low percentages of tropical trees, however, show that dense tropical forest formations never existed in the region and that tropical trees were restricted to wadi banks where they benefited from fresh water availability. The regional landscape remained open, characterized by extended herbaceous plant communities, dominated by grasses and containing numerous Saharan and Sahelian elements. We suggest that both low and high altitudes received greater rainfall at that time, allowing persistent fresh water conditions at Yoa (Kröpelin et al., 2008; Eggermont et al., 2008; Gasse, 2000; Lézine et al., 2011). Rainfall led to the persistence of tropical trees in gallery forests and to the widespread expansion of grasses in the lowlands. It was also responsible for increased surficial runoff/river flows from the Tibesti Mountains which carried Erica arborea pollen grains to the core site. This agrees with Bruneau de Miré and Quezel (1959) and Thinon et al. (1996), who noted an Erica arborea expansion in the Saharan massifs during the midHolocene linked to climate conditions wetter than today with mean annual rainfall around $200-500 \mathrm{~mm}$. This expansion of upland plant communities is consistent with the significant contribution of C3 plants (likely Ericaceae) simulated at $6 \mathrm{ka}$ (not shown).

Climate simulations for $6 \mathrm{ka}$ confirm that more than $75 \%$ of wind events originated from south-west and the monsoonal flow penetrated as far north as Lake Yoa. Precipitation events were characterized by deep convection developing over the region at the expense of subsidence (Fig. 6). The rainy season was more intense and longer than at present, lasting from May to November with a maximum in JulyAugust where precipitation exceeded $3 \mathrm{~mm} \mathrm{day}^{-1}$. The annual mean rainfall reached $1.16 \mathrm{~mm} \mathrm{day}^{-1}\left(\sim 420 \mathrm{~mm} \mathrm{yr}^{-1}\right)$, which is in good agreement with estimates by Kröpelin et al. (2008). The dry spells did not exceed 10 months, meaning that there was only a limited number of entirely dry years. 


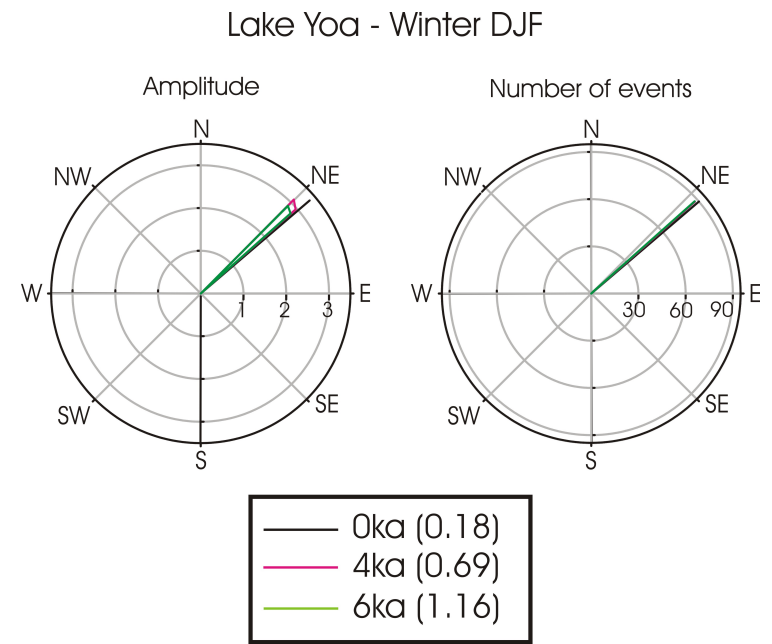

Lake Yoa - Summer JJAS

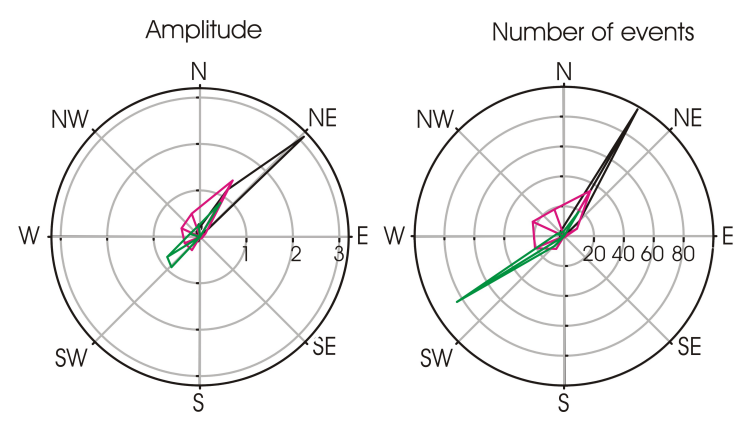

Fig. 5. Number of wind events and mean wind speed as a function of wind direction diagnosed over Lake YOA region $\left(17.5^{\circ} \mathrm{E}-\right.$ $22.5^{\circ} \mathrm{E}, 17^{\circ} \mathrm{N}-22^{\circ} \mathrm{N}$ averaged) from the daily model outputs for (a) winter time (DJF) and (b) summer time (JJAS) and the 3 climate periods considered in this study: $6 \mathrm{ka}, 4 \mathrm{ka}$ and present. Units for the wind amplitude: $\mathrm{ms}^{-1}$.

The climate characteristics simulated for 6 ka thus accurately describe the first period recorded at Yoa. They are similar to those found today in areas under predominant monsoon influence. From 4750 to $2700 \mathrm{cal}$ yr BP, the disappearance of most of tropical humid indicators and their replacement by Sahelian (Sudano-Sahelian, then Sahelo-Saharan) elements record the progressive establishment of dry environmental conditions in the lowlands. This transition occurred in two main steps: with the retreat of the Sudanian trees from 4750 to $4000 \mathrm{yr}$ BP; and the retreat of the Sahelian trees from 4000 to $3250 \mathrm{cal}$ yr BP. At that time, we can consider that the modern distribution of the modern phytogeographical units in Northern Chad, with Sahelian trees restricted to the slopes of the Ennedi and Tibesti massifs (Fig. 1), was completed. The progressive increase, from 4000 cal yr BP onwards, of Tribulus, Boerhavia and Blepharis, which are therophytics with a very short life cycle (Gillet, 1968) and thus well adapted to long rainless periods, confirms the establishment of longer dry seasons compared to the previous period (i.e. a

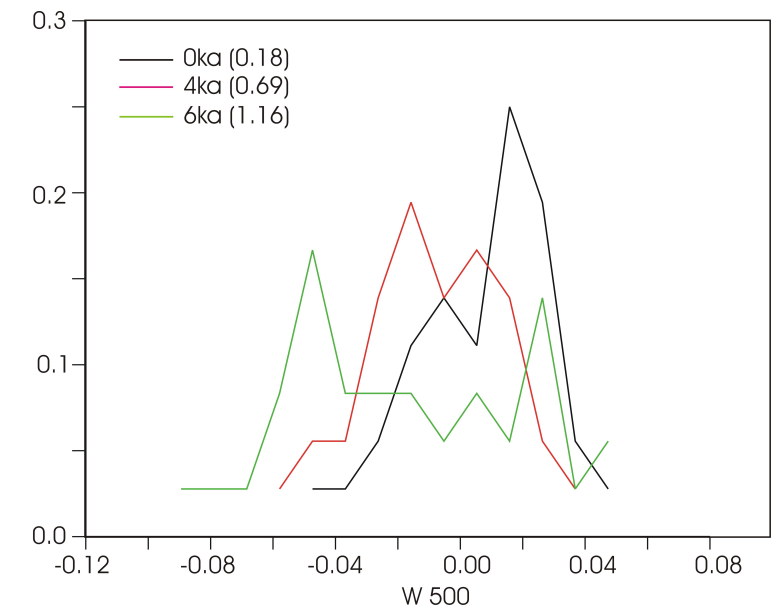

Fig. 6. Probability density function of $500 \mathrm{hPa}$ (w500, in $\mathrm{hPa} \mathrm{s}^{-1}$ ) vertical velocity over Lake Yoa region $\left(17.5-22.5^{\circ} \mathrm{E}, 17-22^{\circ} \mathrm{N}\right)$ for $6 \mathrm{ka}$ (green), $4 \mathrm{ka}$ (red) and ctrl (black). Positive values represent subsidence regions and negative values convective regions. Vertical velocity is used as a proxy for convection.

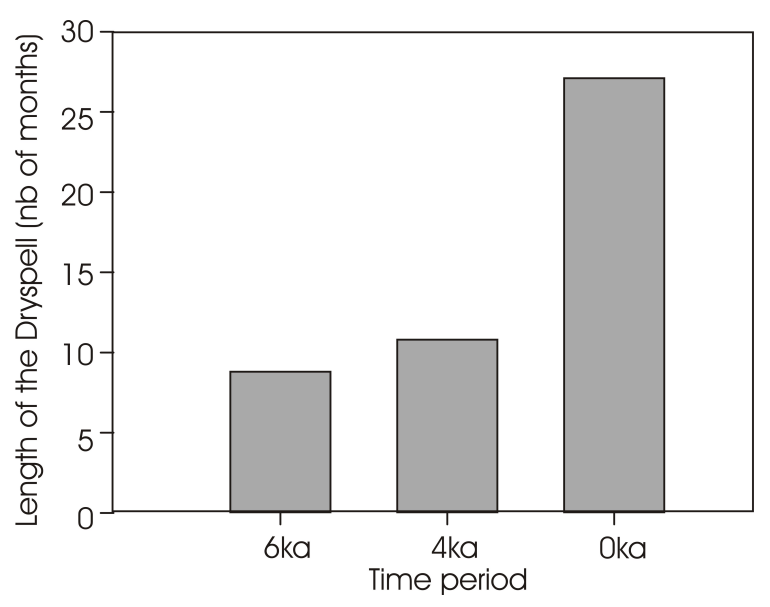

Fig. 7. Mean length of dry spells as simulated at Yoa for $6 \mathrm{ka}, 4 \mathrm{ka}$ and $0 \mathrm{ka}$. Because of the length of the simulations used to compute a continuous dry climate would be represented by a length of 492 months.

11 month simulated dry spell at $4 \mathrm{ka}$ compared to 8.8 month dry spell at $6 \mathrm{ka}$, Fig. 6). This pattern is also reported in the Tassili from dendrochronological data (Cremaschi and Zerboni, 2009). However, the brief return to wet conditions between 3260 and 1440 cal yr BP in this later site is not recorded at Yoa. Pollen transport from the Tibesti Mountains remained, though decreasing, until roughly $3000 \mathrm{cal} y \mathrm{BP}$, indicating that rains persisted at altitude. This corroborates earlier findings by Jäkel (1979), who notes that fluvial terraces still formed at 4600 and $3500 \mathrm{cal} \mathrm{yr} \mathrm{BP}$ in the Enneri Zoumri-Bardagué-Arayé (Tibesti), although they were less developed than those during the early Holocene maximum. 


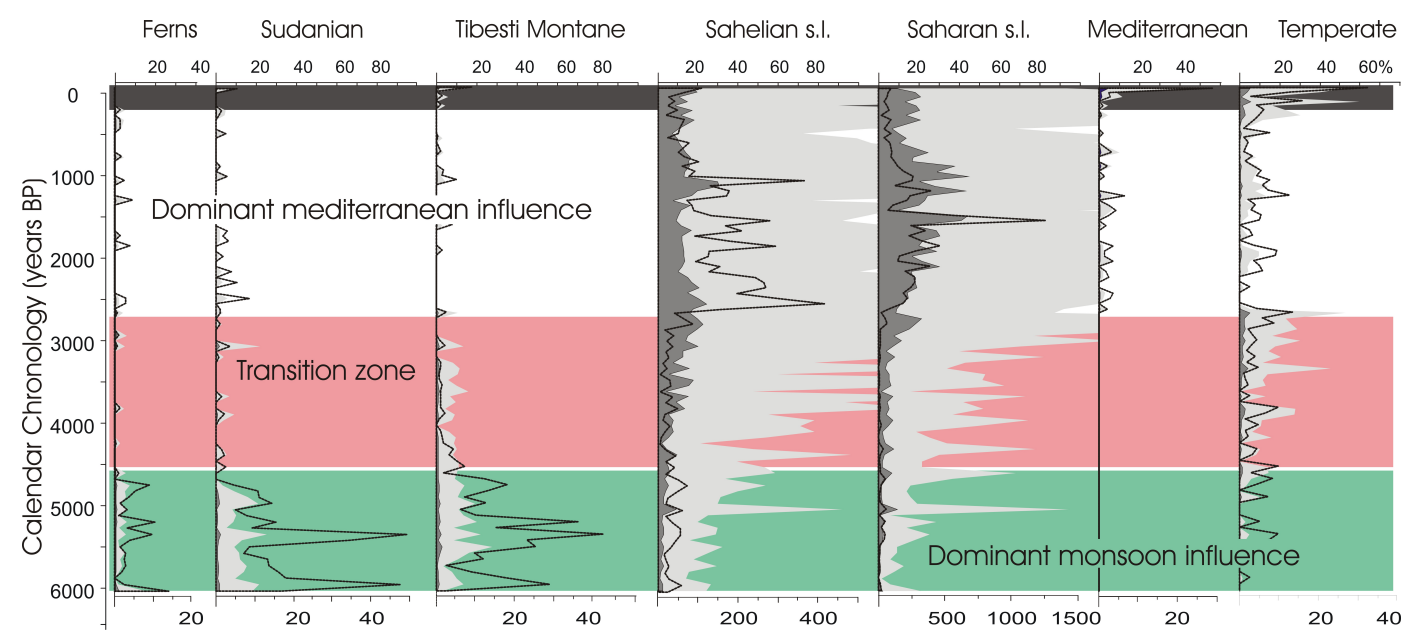

Fig. 8. Lake Yoa main phytogeographical groups. Percentages are indicated in dark grey and magnification (10 times) in light grey. Influxes are shown with dashed black lines. Note that the scales differs for Sahelian (s.1.) and Saharan pollen types which largely dominate the pollen assemblages. This figure shows the main pollen groups corresponding to three main climate regimes which occurred at Yoa from a monsoon dominated climate regime at $6 \mathrm{ka}$ to a Mediterranean dominated climate regime at present. Colors refer to Figs. 4 and 5.

It is also in agreement with Cremaschi and Zerboni (2009), who note that the period between 5990 and 3520 cal yr BP was characterized by noticeable fluvial activity in the wadi Tannezzuft (eastern Tassili). However, the significant presence of Pinus pollen during this time shows that northerly wind fluxes had already begun to strengthen.

The 4 ka simulation is representative of this transition period. The JJAS wind directions (Fig. 5) were quite unstable and covered a wide range of directions, showing a substantial amount of days with wind blowing from the western to northern quadrant. Similar to today, a large portion of events also came from the East-Northeast (Table 1). The transition between the two opposite $6 \mathrm{ka}$ and present day patterns is also found in the convection regimes (Fig. 6). Deep convection is not present in the $4 \mathrm{ka}$ simulation, whereas medium to low convection is dominant in JJAS. However, the length of the rainy season is quite similar to the $6 \mathrm{ka}$ pattern. The differences in precipitation occur only during the second half of the rainy season starting in July, which explains an annual mean precipitation only half that of occurring at $6 \mathrm{ka}$ (Fig. 4). As for $6 \mathrm{ka}$, the continuous period of dry months was generally disrupted by the rainy season in each year, explaining why dry spells did not exceed 11 months. However, due to interannual variability, low rainfall during certain years did in fact have a notable impact on the vegetation. In addition, winter characteristics were only marginally affected at $6 \mathrm{ka}$ and $4 \mathrm{ka}$ (Fig. 5, Table 1). The only differences are found for wind amplitude: the wind speed reaches $3.35 \mathrm{~m} \mathrm{~s}^{-1}$ and then reduces to 2.96 and $2.81 \mathrm{~m} \mathrm{~s}^{-1}$ for $4 \mathrm{ka}$ and $6 \mathrm{ka}$, respectively. During boreal summer, the situation is more contrasted between the different periods. Therefore, we suggest that changes in boreal summer conditions were the most marked differences between these two periods.
From 2700 onwards, the increase in psammophilous plant types (mainly Cornulaca, Ephedra) (White, 1986) confirms the local expansion of sand dunes around Lake Yoa (Kröpelin et al., 2008). The considerable increase in pollen taxa of northern Mediterranean (and Saharo-Mediterranean) origin, mainly Artemisia and Olea, indicates a complete reversal of prevailing winds to a predominant NE-SW direction as is the case today. This is reflected on the simulated wind compasses during summer (Fig. 5). It is probable that these winds were even enhanced by the corridor morphology of the Ounianga plateaus between the Tibesti and the Ennedi massifs. Artemisia pollen grains are present in the lower levels of our record (pollen zones 1 and 2), but only sporadically with values less than $1 \%$ corresponding to conditions usually found in early- to mid-Holocene levels of all the Saharan lowland sites at Selima (Ritchie and Haynes, 1987), Oyo (Ritchie et al., 1985) and Chemchane (Lézine et al., 1990). This can be interpreted as reflecting moderate NE trade wind fluxes. The percentages of Artemisia recorded in Lake Yoa pollen zone 3 are considerably higher (up to $8 \%$ ), suggesting that the Mediterranean-dominated climate regime could have also facilitated the southward expansion of the species. Olea is absent from zone 1 and 2 and only sporadically occurs in zone 3. A single exception occurs in the uppermost level where it reaches $3 \%$, suggesting both the recent reinforcement of the NE trade winds over North Africa and the development of its cultivation in the Mediterranean region. Compared to $4 \mathrm{ka}$, the mean precipitation is dramatically reduced in the control simulations. These drier conditions reflect the increased subsidence over the region (Fig. 6) and are characterized by pronounced dry spells that persist 27.1 months, indicating several consecutive very dry years (Fig. 7). The direct consequence of this was the tremendous expansion of 
the bare soils in our vegetation simulations from $20 \%$ of the box at $6 \mathrm{ka}$ to $90 \%$ at present (not shown).

\subsection{Anthropogenic changes}

The local environment abruptly changed at 1500 cal yr BP, the date on which, according to Cremaschi and Zerboni (2009), due to a dramatic increase in regional dryness, the oases of wadi Tanezzuft contracted to their present state. It is probable that the establishment of oasis agriculture at Yoa at this date corresponded to a search for additional resources to ensure the food security of Saharan populations in the face of the increasing regional drought.

Hyphaene pollen are sporadically found in early to midHolocene Saharan sites at Bir Atrun (Ritchie and Haynes, 1987), Oyo (Ritchie et al., 1985) and Gobero (Sereno et al., 2008) from 10000 to 5500 cal yr BP. Here they are assigned to Hyphaene thebaica palm trees, which currently characterize the northern African dry lands and grow in areas benefiting from the proximity of underground waters, such as in oases and wadi beds (White, 1986). Hyphaene pollen are also present in Lake Yoa zone 1 and 2, confirming the wide distribution of wild doum palms in northern Africa during the Holocene. The fruit of Hyphaene thebaica is edible, its fiber and leaflets are used to weave baskets, and its trunk is used as building material. It has long been collected, as demonstrated by charred fruits fragments recovered at the late Pleistocene Kubbaniyan sites in the Nile Valley (Wendrof et al., 1988). Hyphaene thebaica was also long considered a sacred tree by the ancient Egyptians, and its first representation goes back to the New Empire between roughly 1552 and 1080 BC (Baum, 1988). In Lake Yoa zone 3, the occurrence of Hyphaene pollen is continuous, and its percentages/influx values increase significantly, suggesting that doum palm trees were, if not cultivated, at least intentionally favored by local inhabitants after $1500 \mathrm{cal} \mathrm{yr} \mathrm{BP}$ at Yoa. They were replaced after $850 \mathrm{cal}$ yr BP by Phoenix dactylifera, which has a better nutrititional value. The establishment of such a plantation at Yoa occurs much later than in the Middle East where the earliest consumption of dates come from Neolithic settlements of Abu Dhabi and Kuwait around the late 6th-early 5th millennium BC (Méry and Tengberg, 2009). In Egypt, Phoenix dactylifera could have been introduced into the Nile Valley during the pre-dynastic period (Roubet and El-Hadidi, 1981). In both regions, date palm plantations became increasingly common from the 3rd millennium BC (Cleuziou and Costantini, 1980; Baum, 1988). Fossil date pits were found much later in Libya, at levels dated from $2145 \mathrm{cal}$ yr BP at Uan Muhuggiag (Tadrart Acacus), and between 2800 and 2400 cal yr BP in Fezzan (Van der Veen, 1995). A date palm oasis still exists at Yoa where it benefits from the proximity of the groundwater. Here, agriculture also included wheat (Capot-Rey, 1961), explaining the presence of a Cerealia pollen grain in the upper most level of our diagram.

\section{Conclusions}

Comparison between pollen-based paleoenvironmental reconstructions at Yoa (Northern Chad) and climate simulations point to two main features: (1) the shift from an earlier predominantly monsoonal climate regime to one dominated by northern Mediterranean fluxes occurred after $4000 \mathrm{cal}$ yr BP. The direct consequence of this was the establishment of the modern desert environment at Yoa at 2700 cal yr BP. (2) Changes in climate parameters (simulated rainfall amount and dry spell length) between 6 and 4 ka were comparatively minor. However, changes in the seasonal distribution of precipitation during this time dramatically affected the vegetation composition and were at the origin of the retreat of tropical plant communities from Lake Yoa.

\section{Supplementary material related to this article is available online at: http://www.clim-past.net/7/1351/2011/ cp-7-1351-2011-supplement.pdf.}

Acknowledgements. This research is part of a French project funded by the National Agency for Research in France (projet ANR-vulnerability "SAHELP"). Thanks are due to S. Kröpelin (University of Cologne, Germany) for accessibility to samples as part of a collaborative research project of the Deutsche Forschungsgemeinschaft (ACACIA), D. Verschuren (Gent University, Belgium) and all the SAHELP partners for fruitful discussions. F. Aptel, J.-P. Cazet (CNRS, Gif-sur-Yvette) and S. Ivory (Arizona University) assistance is acknowledged. AML and GK are supported by CNRS and PB by CEA. WZ was supported by ANR through a post-doctoral grant as part of the SAHELP project. LSCE contribution no. 4612 .

Edited by: D. Fleitmann

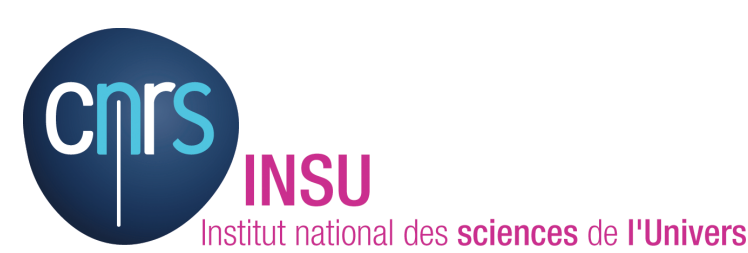

The publication of this article is financed by CNRS-INSU.

\section{References}

African Plant database: http://www.ville-ge.ch/musinfo/bd/cjb/ africa/2009 (last access: December 2011), 2009.

Arkell, A. J.: Wanyanga and an archaeological reconnaissance of the south-west Libyan desert: the British Ennedi expedition, 1957, London, Oxford University Press, 1964.

Baum, N.: Arbres et arbustes de l'Egypte ancienne, la liste de la tombe thébaine d'Ineni (no. 81), Orientalia Lovaniensia Analecta 31, p.381, 1988. 
Beniston, M., Stephenson, D. B., Christenson, O. B., Ferro, C. A. T., Frei, C., Goyette, S., Halsnaes, K., Holt, T., Jylhä, K., Koffi, B., Palutikof, J., Schöll, R., Semmler, T., and Woth, K.: Future extreme events in European climate: an exploration of regional climate model projections, Climate Change 81, 71-95, 2007.

Berger, A. L.: Long Term Variations of Daily Insolation and Quaternary Climatic Changes, J. Atmos. Sci., 35, 2362-2367, 1978.

Bonnefille, R. and Riollet, G.: Pollens des savanes d'Afrique orientale, CNRS, Paris, p.140, 1980.

Bruneau de Miré, P. and Gillet, H.: Contribution à l'étude de la flore du massif de l'Aïr, Journal d'Agriculture Tropicale et de Botanique Appliquée, 3, 5-6, 221-247; 3, 7-8, 422-442; 3, 12, 857-886, 1956.

Bruneau de Miré, P., and Quézel, P.: Sur la présence de la bruyère en arbre (Erica arborea L.) sur les sommets d l'Emi Koussi (Massif du Tibesti), CR Société Biogéographie, Paris, 315, 66-70, 1959.

Capot-Rey, R.: Borkou et Ounianga, étude de géographie régionale. Institut de Recherches Sahariennes, Université d'Alger, Mémoire, 5, p.182, 1961.

Caratini, C., Tissot, C., and Frédoux, A.: Caractérisation des aérosols désertiques à Niamey (Niger) par leur contenu pollinique, Institut Français de Pondichéry, Travaux de la Section Scientifique et Technique, 25, 251-268, 1988.

Charney, J. G., Stone, P. H., and Quirk, W. J.: Drought in the Sahel: A biogeophysical feedback mechanism, Science, 187, 434-435, 1975.

Claussen, M., Kubatzki, C., Brovkin, V., Ganopolski, A., Hoelzmann, P., and Pachur, H. J.: Simulation of an abrupt change in Saharan vegetation at the end of the mid- Holocene, Geophys. Res. Lett., 24, 2037-2040, 1999.

Cleuziou, S. and Costantini, L.: Premiers éléments sur l'agriculture protohistorique de l'Arabie orientale, Paléorient, 6, 245-251, 1980.

Cremaschi, M. and Zerboni, A.: Early to Middle Holocene landscape exploitation in a drying environment: Two case studies compared from the central Sahara (SW Fezzan, Libya), Comptes Rendus Geosciences, 341, 689-702, 2009.

deMenocal, P. B., Ortiz, J., Guilderson, T., Adkins, J., Sarnthein, M., Baker, L., and Yarusinski, M.: Abrupt onset and termination of the African Humid Period: Rapid climate response to gradual insolation forcing, Quaternary Sci. Rev., 19, 347-361, 2000.

Eggermont, H., Verschuren, D., Fagot, M., Rumes, B., and van Bocxlaer, B.: Aquatic community response in a groundwater-fed desert lake to Holocene dessication of the Sahara, Quaternary Sci. Rev., 27, 2411-2425, 2008.

Gasse, F.: Hydrological changes in the African tropics since the Last Glacial maximum, Quaternary Sci. Rev., 19, 189-211, 2000.

Gillet, H.: Le peuplement végétal du massif de l'Ennedi (Tchad), Thesis, University of Paris, p.206, 1968.

Hely, C., Braconnot, P., Watrin, J., and Zheng, W. P.: Climate and vegetation: Simulating the African humid period, Comptes Rendus Geoscience, 341, 671-688, 2009.

Hoelzmann, P., Jolly, D., Harrison, S. P., Laarif, F., Bonnefille, R., and Pachur, H.-J.: Mid-Holocene land-surface conditions in northern Africa and the Arabian Peninsula: a data set for the analysis of biogeophysical feedbacks in the climate system, Global Biogeochem. Cy., 12, 35-51, 1998.
Hourdin, F., Musat, I., Bony, S., Braconnot, P., Codron, F., Dufresne, J.-L., Fairhead, L., Filiberti, M.-A., Friedlingstein, P., Grandpeix, J.-Y., Krinner, G., Levan, P., Li, Z. X., and Lott, F.: The LMDZ4 general circulation model : climate performance and sensitivity to parametrized physics with emphasis on tropical convection, Clim. Dynam., 27, 787-813, 2006.

Hutchinson, J. and Dalziel, J. M.: Flora of West Tropical Africa, Whitefriars, London, 1954-1972.

Jäkel, D.: Run-off and fluvial formation processes in the Tibesti Mountains as indicators of climatic history in the central Sahara during the late Pleistocene and Holocene, Palaeoecol. Africa, 11, 13-44, 1979.

Kaplan, J. O., Bigelow, N. H., Prentice, I. C., Harrison, S. P., Bartlein, P. J., Christensen, T. R., Cramer, W., Matveyeva, N. V., McGuire, A. D., Murray, D. F., Razzhivin, V. Y., Smith, B., Walker, D. A., Anderson, P. M., Andreev, A. A., Brubaker, L. B., Edwards, M. E., and Lozhkin, A .V.: Climate change and arctic ecosystems II. Modeling, paleodata-model comparisons, and future projections, J. Geophys. Res., 108, 8171, doi:10.1029/2002JD002559, 2003.

Krinner, G., Mangerud, J., Jakobsson, M., Crucifix, M., Ritz, C., and Svendsen, J. I.: Enhanced ice sheet growth in Eurasia owing to adjacent ice-dammed lakes, Nature, 427, 429-432, 2004.

Krinner, G., Braconnot, P., Lézine, A.-M., Ramstein, G., Zheng, W., Sepulchre, P., Grenier, C., and Hély, C.: Strong timescaledependent feedbacks on the North African Holocene climate by lakes and wetlands. Geophysical Research Letters, submitted, 2011.

Kröpelin, S., Verschuren, D., Lézine, A.-M., Eggermont, H., Cocquyt, C., Francus, P., Cazet, J.-P., Fagot, M., Rumes, B., Russell, J. M., Conley, D. J., Schuster, M., von Suchodoletz, H., and Engstrom, D. R.: Climate-driven ecosystem succession in the Sahara: the last 6000 years, Science, 320, 765-768, 2008.

Kuper, R. and Kröpelin, S.: Climate-Controlled Holocene Occupation in the Sahara: Motor of Africa's Evolution, Science, 313, 803-807, 2006.

Lebrun, J.-P. and Stork, A. L.: Tropical African Flowering Plants, Ecology and Distribution, Conservatoire et Jardin Botaniques, Genève, 4 vols, 2003-2008.

Lézine, A.-M.: Les variations de la couverture forestière mésophile d'Afrique occidentale au cours de l'Holocène, Comptes rendus de l'Académie des Sciences, Paris, 307, 439-445, 1988.

Lézine, A.-M.: Timing of vegetation changes at the end of the Holocene Humid Period in desert areas at the northern edge of the Atlantic and Indian monsoon systems, Comptes Rendus Geoscience, 341, 750-759, 2009.

Lézine, A. M. and Hooghiemstra, H.: Land-sea comparisons during the last glacial-interglacial transition: pollen records from West Tropical Africa, Palaeogeogr. Palaeocl., 79, 313-331, 1990.

Lézine, A.-M., Casanova, J., and Hillaire-Marcel, C.: Across an early Holocene humid phase in western Sahara, pollen and isotope stratigraphy, Geology, 18, 264-267, 1990.

Lézine, A.-M., Hély, C., Grenier, C., Braconnot, P., and Krinner, G.: Sahara and Sahel vulnerability to climate changes, lessons from Holocene hydrological data, Quaternary Sci. Rev., 30, 30013012, 2011. 
Liu, Z., Wang, Y., Gallimore, R., Gasse, F., Johnson, T., deMenocal, P., Adkins, J., Notaro, M., Prentice, I. C., Kutzbach, J., Jacob, R., Behling, P., Wang, L., and Ong, E.: Simulating the transient evolution and abrupt change of Northern Africa atmosphere-oceanterrestrial ecosystem in the Holocene, Quaternary Sci. Rev., 26, 1818-1837, 2007.

Maire, R. and Monod, Th.: Etudes sur la flore et la végétation du Tibesti, Mémoires de l'institut français d'Afrique noire, 8, p.140, 1950.

Maley, J.: Contribution à l'étude du Bassin tchadien. Atlas des pollens du Tchad, Bulletin du Jardin Botanique National de Belgique, 40, 29-48, 1970.

Marzin, C. and Braconnot, P.: The role of the ocean feedback on Asian and African monsoon variations at $6 \mathrm{kyr}$ and $9.5 \mathrm{kyr} \mathrm{BP}$, Comptes Rendus Geosciences, 341, 643-655, 2009.

Méry, S. and Tengberg, M.: Food for eternity? The analysis of a date offering from a 3rd millennium $\mathrm{BC}$ grave at Hili N, Abu Dhabi (United Arab Emirates, J. Archaeol. Sci., 36, 2012-2017, 2009.

Ozenda, P.: Flore et végétation du Sahara, CNRS Ed., Paris, p.662, 2004.

Pons, A. and Quézel, P.: A propos de l'étude palynologique de quelques sédiments sahariens récents, Bulletin de Liaison Saharienne, Alger, 29, 77-80, 1958.

Quézel, P.: Contribution à l'étude de la flore et de la végétation du Hoggar, Institut de Recherches Sahariennes, Université d'Alger, p.160, 1954.

Quézel, P.: Mission botanique au Tibesti, Institut de Recherches Sahariennes, Université d'Alger, Mémoire no. 4, p.357, 1964.

Quézel, P.: La végétation du Sahara, Gustav Fischer, Stuttgart, p.333, 1965.

Quézel, P. and Martinez, C.: Etude palynologique de deux diatomites du Borkou (Territoire du Tchad A.E.F.), Bulletin de la Société d'Histoire naturelle d'Afrique du Nord, 49, 230-244, 1958.

Rayner, N. A. A., Parker, D. E., Horton, E. B., Folland, C. K., Alexander, L. V., Rowell, D. P., Kent, E. C., and Kaplan, A.: Global analyses of sea surface temperature, sea ice, and night marine air temperature since the late nineteenth century, J. Geophys. Res.-Atmos., 108, 4407, doi:10.1029/2002JD002670, 2003.

Renssen, H., Brovkin, V., Fichefet, T., and Goosse, H.: Simulation of the Holocene climate evolution in Northern Africa: the termination of the African Humid Period, Quatern. Int., 150, 95-102, 2006.

Ritchie, J. C. and Haynes, C. V.: Holocene vegetation zonation in the eastern Sahara, Nature, 330, 645-647, 1987.

Ritchie, J. C., Eyles, C. H., and Haynes, C. V.: Sediment and pollen evidence for an early to mid-Holocene humid period in the eastern Sahara, Nature, 314, 352-355, 1985.

Roubet, C. and El-hadidi, M. N.: 20.000 ans d'environnement préhistorique dans la vallée du Nil et le désert égyptien, Bulletin de l'Institut français d'archéologie orientale, 81, 445-470, 1981.

Schulz, E.: Zur Vegetation der östlichen zentralen Sahara und zu ihrer Entwicklung im Holozän, Würzburger Geographische Arbeiten, 51, p.194, 1980.
Schulz, E. and Lueke, M.: A two year pollen calendar for traditionally produced honey types from Gaya, southern Niger, Grana, 33, 254-259, 2009.

Sereno, P. C., Garcea, E. A. A., Jousse, H., Stojanowski, C. M., Saliège, J.-F., Maga, A., Ide, O. A., Knudson, K. J., Mercuri, A.M., Stafford, T. W., Kaye, T. G., Giraudi, C., Massamba N'siala, I., Cocca, E., Moots, H. M., Dutheil, D. B., and Stivers, J. P.: Lakeside Cemeteries in the Sahara: 5000 Years of Holocene Population and Environmental Change, PLoS ONE, 3, e2995, doi:10.1371/journal.pone.0002995, 2008.

Thinon, M., Ballouche, A., and Reille, M.: Holocene vegetation of the Central Saharan Mountains: the end of a myth, Holocene, 6, 457-462, 1996.

Tschudy, R. H.: Relationship of palynomorphs to sedimentation, in: Aspects of palynology, edited by: Tschudy, R. H. and Scott, R. A., Wiley lnterscience, New York, 79-96, 1969.

Van Campo, M.: Pollen analyses in the Sahara, in: Problemes in Prehistory: North Africa and the Levant, edited by: Wendorf, F. and Marks, E., Southern Methodist University Press, Dallas, 45-64, 1975.

Van der Veen, M.: Ancient agriculture in Lybia: a review of the evidence, Acta Palaeobotanica, 35, 85-98, 1995.

Vincens, A.: Palynologie des environnements actuels et PlioPléistocène à l'Est du Lac Turkana (Kenya), Unpublished Thesis, Université Aix-Marseille II, p.244, 1982.

Vincens, A., Schwartz, D., Elenga, H., Reynaud-Farrera, I., Alexandre, A., Bertaux, J., Mariotti, A., Martin, L., Meunier, J.-D., Nguetsop, F., Servant, M., Servant-Vildary, S., and Wirrmann, D.: Forest response to climate changes in Atlantic Equatorial Africa during the last 4000 years BP and inheritance on the modern landscapes, J. Biogeogr., 26, 879-885, 1999.

Vincens, A., Lézine, A.-M., Buchet, G., Lewden, D., Le Thomas, A., and contributors: African Pollen Database inventory of tree and shrub pollen types, Rev. Palaeobot. Palynol., 145, 135-141, 2007.

Watrin, J., Lézine, A.-M., Gajewski, K., and Vincens, A.: PollenPlant-Climate relation in sub-Saharan Africa, J. Biogeogr., 34, 489-499, 2007.

Watrin, J., Lézine, A.-M., and Hély, C.: Plant migration and ecosystems at the time of the "green Sahara", CR Geosci., 341, 656670, 2009.

Wendrof, F., Schild, R., Close, A. E., Hillman, G. C., Gautier, A., van Neer, W., Donahue, D. J., Jull, A. J. T., and Linick, T. A.: New radiocarbon dates and late Plalaeolithic diet at Wadi Kubbaniya, Egypt. Antiquity, 62, 279-283, 1988.

White, F.: La végétation de l'Afrique, ORSTOM, UNESCO, p.384, 1986.

Wickens, G. E.: The flora of Jebel Marra (Sudan Republic) and its geographical affinities, Royal Botanic Gardens, Kew Bulletin Additional Series, 5, p.368, 1976.

World Climate Database: http://www.fao.org/sd/locclim/srv/ locclim.hom (last access: December 2011), 2007. 